\title{
MEMBANGUN STUDI KELAYAKAN BISNIS DALAM PERSPEKTIF MAQASHID SYARIAH YANG DIPERLUAS
}

\author{
Vega Wafaretta \\ Universitas Brawijaya, Jl. MT. Haryono 165, Malang \\ Surel: wafaretta.vega@gmail.com
}

\begin{abstract}
Abstrak. Membangun Studi Kelayakan Bisnis Dalam Perspektif Maqashid Syariah yang Diperluas. Studi kelayakan bisnis dilakukan untuk memperkirakan return di masa depan dan mengelola risiko. Studi masih bersifat materi saja, dengan tujuan yang kapitalistik bagi pemilik. Islam sebagai rahmatan lil 'alamiin (rahmat bagi seluruh alam) seharusnya dijadikan dasar untuk mencapai kemaslahatan sebagai tujuan syariah (maqashid syariah). Oleh karena itu, dirasakan perlu adanya rekonstruksi studi kelayakan bisnis dalam perspektif extended maqashid sharia (tujuan syariah yang diperluas) untuk mencapai maslahah, yaitu memelihara agama, jiwa, akal, harta, serta menambahkan pemeliharaan lingkungan dan persaudaraan (ukhuwah), tetapi tidak termasuk memelihara keturunan. Teori Mamah Dedeh digunakan untuk membangun studi kelayakan bisnis dengan berdasar pada biografi dan cara dakwahnya.
\end{abstract}

\begin{abstract}
Building Business Feasibility Study in the Perspective of Extended Maqashid Sharia. Feasibility study is conducted to estimate future returns and manage risk. Study is still with the goal of capitalistic for owners. Islam as rahmatan lil 'alamiin (mercy for all the worlds) should be used as the basis for achieving the benefit as the goal of sharia (maqashid shariah). Therefore, there is a need perceived for reconstruction of the feasibility study in the perspective of the extended maqashid sharia (extended Islamic goal) to reach maslahah, namely maintaining religion, life, intellect, property, as well as adding nurturing environment and fraternity (brotherhood), but does not include maintaining descent. Mamah Dedeh theory is used to build a business feasibility study based on the biography and the way of her 'dakwah'.
\end{abstract}

Kata kunci: Studi Kelayakan Bisnis, Extended Maqashid Sharia, Mamah Dedeh

Tujuan bisnis menjadi poin penting sebelum mulai menjalankan bisnis. Paradigma lama yang bertujuan memaksimalkan laba dan nilai pemangku kepentingan ternyata telah menimbulkan konsekuensi negatif. Bisnis tampak menjadi sesuatu yang tamak, egois, dan jahat (Mackey 2007). Tujuan bisnis akan diikuti dengan pembuatan keputusan terkait penanaman modal melalui analisis atau studi kelayakan bisnis.

Hofstrand dan Holz-Clause (2009) secara jelas membedakan studi kelayakan dengan rencana bisnis (business plan) dengan menegaskan bahwa keduanya memiliki peran yang berbeda. Stu- di kelayakan adalah alat untuk menginvestigasi kelayakan dari proyek yang prospektif, sedangkan rencana bisnis adalah alat untuk merencanakan tindakan yang dibutuhkan untuk mengambil atau menjalankan proposal proyek dari ide menuju realitas. Studi kelayakan bisnis akan dapat menunjukkan apakah proyek/bisnis itu layak sebelum dilakukan langkah selanjutnya atau sumber dana yang digunakan. Dengan kata lain, studi dilakukan untuk memastikan apakah bisnis dapat menjamin investasi waktu dan uang lebih lanjut (Thompson 2003).

Studi kelayakan bisnis mencakup produk/jasa, teknologi,

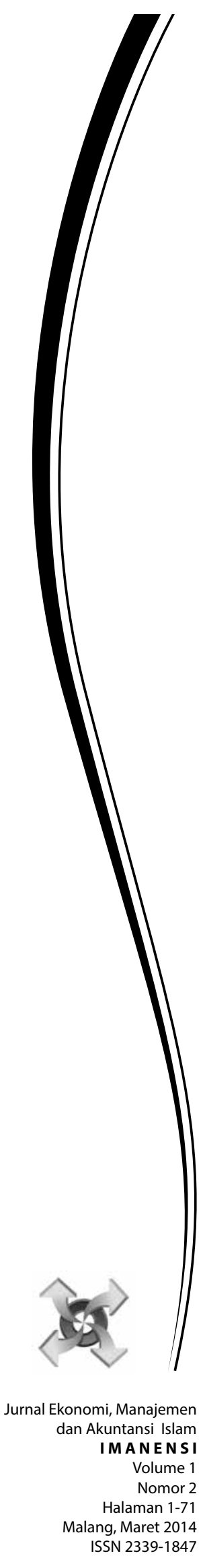


lingkungan pasar, kompetisi, industri, model bisnis, strategi pemasaran dan penjualan, produksi, manajemen dan sumber daya manusia, properti intelektual, isu regulasi/lingkungan, faktor risiko, pertimbangan waktu, proyeksi finansial/keuangan, kebutuhan modal dan strategi, serta rekomendasi akhir (Thompson 2003). Sedangkan, menurut Graaskamp (1972), komponen analisis kelayakan terdiri dari tujuan perusahaan untuk siapa studi dilakukan, tren pasar untuk mengidentifikasi area peluang yang konsisten dengan tujuan, segmentasi pasar, batasan hukum-politik, batasan estetika-etika, batasan dan alternatif fisik-teknis, serta sintesis keuangan. Sintesis keuangan berkisar antara spesfifikasi profit center, anggaran modal, pola pendapatan operasi, perencanaan keuangan, strategi pajak, pengukuran profitabilitas, serta indeks risiko.

Analisis kelayakan tidak dapat mengabaikan risiko yang terkandung di dalamnya. Analisis diharapkan dapat memperkirakan return di masa depan dan mengelola risiko. Hal ini didukung dengan Directorate General Regional Policy - European Comission (2008) bahwa analisis investasi mengharapkan tingkat pengembalian yang jelas agar dapat menutup modal awal, dalam hal ini arus kas dan laba. Begitu pula menurut Björnsdóttir (2010) bahwa bisnis yang layak adalah bisnis yang dapat menghasilkan arus kas dan laba memadai, menahan risiko, dapat bertahan hidup dalam jangka panjang, dan memenuhi tujuan dari para pendirinya.

Studi kelayakan bisnis dalam sistem konvensional ini masih melekat pada hal yang bersifat materi. Seperti yang dinyatakan oleh Weber (1927) bahwa keberadaan akun modal yang mendukung perhitungan rasional atas laba merupakan ciri khusus kapitalisme (books.google.co.id). Kemudian Toms (2010) mengkritik kapitalisme melalui survei sejarah sistematis atas perhitungan profitabilitas. Terdapat suatu pemahaman bahwa hubungan antara akuntansi dan kapitalisme merupakan bagian transisi dalam pengembangan mental kalkulatif. Ketidaksesuaian sistem konvensional tidak hanya terbatas pada mental kalkulatif khususnya dalam accounting dan rate of return, tetapi termasuk juga cara perhitungan yang digunakan melalui net present value sebagai metode berbasis arus kas.

Menurut Björnsdóttir (2010), metode arus kas lebih dipilih daripada metode yang berbasis laba akuntansi karena metode arus kas memperhitungkan nilai waktu dari uang, sedangkan metode laba akuntansi tidak. Untuk melihat nilai waktu dari uang (yang mana uang saat ini akan memiliki nilai yang berbeda dengan di masa datang), maka discount rate yang berlaku akan digunakan.

Discount rate yang digunakan merupakan bagian riba', yang jelas dilarang dalam Islam. Kemudian, muncullah pemaparan baru yang lebih sesuai dengan konsep Islam, yaitu mengganti discount rate dengan ekspektasi keuntungan yang digunakan sebagai dasar nominal yang kemudian dikalikan dengan nisbah bagi hasil. Ekspektasi keuntungan ini merupakan bagian dari penilaian bank syariah atas investasi yang ditawarkan oleh nasabah, dan sebagai bahan pertimbangan dalam memutuskan sistem pemberian investasi. Karim (2011) lebih lanjut menjelaskan penilaian yang dapat dilakukan oleh bank syariah terhadap proposal penanaman modal dalam proyek investasi (pemberian pembiayaan) menurut syariah, antara lain: (1) Analisis break even; (2) Analisis perbandingan penanaman modal dalam berbagai alternatif proyek melalui dasar ukuran antara lain Payback Period (PP), Net Present Value (NPV), Benefit Cost Ration (B/C Ratio), dan Internal Rate of Return (IRR); (3) Analisis rasio dengan menggunakan ukuran financial viability, profitabilitas, dan proyeksi atas kinerja; serta (4) Analisis risiko mencakup analisis sensitivitas dan analisis probabilitas.

Tampak bahwa penilaian keuangan mengandung nilai yang sama dengan perhitungan konvensional. Kondisi tersebut bisa jadi merupakan bagian dari conscious capitalism. Seperti dijelaskan oleh Mackey (2007), tujuan tetap sama dengan konvensional yang kapitalistik, yaitu memaksimalkan nilai pemegang saham. Namun, caranya dilakukan dengan mempertimbangkan konsumen, pemasok, investor, komunitas, dan lingkungan, sebagai cerminan adanya kesadaran perlunya memihak konstituensi lain yang berada di sekitar bisnis. Nasr (2009:14) menggunakan istilah Islamic Capitalism. Dicontohkan adanya penggabungan nilai Islam dengan globalisasi yang bisa jadi bersifat materialistik, salah satunya adalah hiburan dan liburan yang disertai dengan hotel mewah.

Faruqi (1998) menanggapi dengan mengajak umat Islam untuk bangun mengonstruksi ilmu pengetahuan berdasarkan jiwa Tauhid. Karakter utama kapitalisme yang utilitarian dan hedonis sebagai wajah 
kapitalisme perlu diubah, bahkan diganti dengan pengetahuan yang didasarkan pada Tauhid. Berdasarkan ulasan tersebut, artikel ini mengusulkan rekonstruksi model studi kelayakan bisnis yang sesuai dengan syariah, khususnya dalam perspektif extended maqashid syariah (tujuan syariah yang diperluas dengan wacana tambahan) untuk mencapai maslahah. Diharapkan akan dapat memberikan output berupa studi kelayakan bisnis sebagai acuan dalam berbisnis secara Islami.

\section{METODE}

\section{Tataran Awal Membangun Kelayakan Bis- nis yang Maslahah}

Islam adalah rahmat bagi seluruh alam, sesuai dengan ayat berikut.

"Dan tiadalah Kami Mengutus kamu, melainkan untuk (menjadi) rahmat bagi semesta alam" (QS Al-Anbiya' 21:107).

Semua ahli tafsir sepakat bahwa maksud ayat ini adalah diutusnya Nabi Muhammad SAW untuk membawa keistimewaan syariat yang melebihi syariat yang lain dengan keistimewaan yang bersifat umum dan berkelanjutan, yaitu syariat yang merupakan rahmat bagi seluruh alam. Sehingga, syariat yang dibawa oleh Nabi menjadi rahmat atau kasih sayang dari Allah SWT bagi seluruh alam.

Kata "al-'alamiin" ditafsir berbeda-beda oleh para mufassir. Ada yang mengatakan bahwa yang dimaksud dengan al-'alamiin adalah orang-orang yang beriman. Pendapat ini diriwayatkan dari Ibnu Zaid, sebagaimana dikemukakan oleh Ath-Thabari. Namun, jumhur mufassir mengatakan bahwa yang dimaksud dengan kata al-'alamiin adalah kaum muslim dan non-muslim. Inilah pendapat yang paling kuat dan paling benar. Sehingga, syariat Nabi Muhammad SAW ditujukan untuk seluruh manusia. Pendapat ini diriwayatakan dari Ibnu Abbas.

Selanjutnya, Ibnu Asyur menjelaskan bahwa yang dimaksud dengan kata al-'alamiin adalah semua manusia bahkan semua makhluk hidup. Karena "al" yang ada pada kata al-'alamiin adalah "al" yang berarti al-istighraq (mencakup semua jenis alam, yaitu manusia atau semua jenis makhluk hidup).

Para ulama ushul fiqh mengartikan rahmat dengan menggunakan istilah kemaslahatan yang selanjutnya dikenal den- gan istilah Maqashid al-Syariah. Kemaslahatan disebut sebagai maqashid al-syari'ah (tujuan syariah), karena kemaslahatan merupakan hasil yang akan dituju dari pemberlakuan syariat. Dengan kata lain, syariat yang ditetapkan Allah SWT kepada manusia bertujuan untuk mewujudkan kemaslahatan manusia di dunia dan di akhirat.

Jika rahmatan lil 'alamiin dikaitkan dengan maqashid al-syariah, maka kemaslahatan sebagai hasil ketundukan pada syariat akan ditujukan bagi semesta alam. Mengacu pada penjelasan Ibnu Asyur, maka kemaslahatan seharusnya ditujukan kepada seluruh makhluk hidup, yaitu manusia, hewan, maupun tumbuhan. Sehingga, maslahah yang diharapkan tidak hanya menyentuh aspek manusia, tetapi juga lingkungan. Pendapat inilah yang akan digunakan lebih lanjut dalam penelitian ini.

\section{Maqashid Syariah}

Dalam kajian ilmu Islam, terdapat tiga wilayah ilmu yang sering dikemukakan ulama, yaitu aqidah (kalam), fiqih (syariah), dan tasaawuf-akhlak. Fiqih kemudian dibagi menjadi dua bagian besar, yaitu (1) Ibadah, yang di dalamnya diatur pola hubungan manusia dengan Tuhan, dan (2) Muamalah yang di dalamnya diatur pola hubungan antara sesama manusia. Al-Qur'an dan As-Sunnah tidak memuat aturan-aturan yang terperinci, sehingga jika terdapat suatu perkara, khususnya dalam bermuamalah, yang tidak terdapat nash khusus dalam Al-Qur'an maupun As-Sunnah, maka perlu dilakukan ijtihad (Mubarak 2002). Oleh karena itu, aspek-aspek hukum terkait praktik muamalah dikembangkan, yaitu dengan mengkaitkannya dengan maqashid syariah.

Secara etimologis, maqashid al-syariah terdiri dari dua kata, yaitu maqashid dan syariah. Maqashid merupakan bentuk jama' dari kata maqshud yang merupakan kata jadian (masdar) qashada yang berarti bermaksud atau menuju sesuatu (Luis Ma'luf dalam Anshori 2003). Kemudian, syariah berarti kebiasaan atau sunnah. Sedangkan, secara terminologis, mengandung pengertian bahwa sesungguhnya syariah itu bertujuan mewujudkan kemaslahatan manusia di dunia dan di akhirat (Asy-Syatibi dalam Anshori 2003).

Kemaslahatan yang hendak diwujudkan itu terbagi kepada tiga tingkatan, yaitu kebutuhan daruriyyah, kebutuhan hajiyyah, dan kebutuhan tahsiniyyah. Pertama, kebu- 
tuhan daruriyyah adalah tingkatan kebutuhan yang harus ada atau dapat disebut sebagai kebutuhan primer. Terdapat lima hal yang termasuk dalam kategori ini, yaitu memelihara agama (hifd al-din), memelihara jiwa (hifd al-nafs), memelihara akal (hifd alaql), memelihara keturunan (hifd al-nasl), dan yang terakhir adalah memelihara harta benda (hifd al-mal). Semua perintah dan larangan syariat bermuara kepada pemeliharaan lima unsur pokok ini (Zein 2005).

Untuk memelihara agama, Islam mewajibkan ibadah seperti shalat, puasa, dan zakat yang harus dilakukan oleh umat $\mathrm{Mu}$ slim. Untuk memelihara jiwa, Islam mewajibkan makan tetapi dalam aturan-aturan tertentu, seperti tidak memakan makanan yang haram (dilarang dalam Islam), tidak boleh makan secara berlebihan, dan menganjurkan untuk berhenti makan sebelum kenyang. Untuk memelihara akal, Islam melarang melakukan perbuatan yang dapat merusak akal, seperti membunuh atau minum minuman yang memabukkan yang dapat menghilangkan akal (kesadaran diri seseorang). Untuk memelihara keturunan, Islam mengatur adanya pernikahan dan melarang zina. Terakhir, untuk memelihara harta, Islam mensyariatkan untuk bekerja dalam upaya yang halal, yaitu tidak mengambil harta orang lain dengan mencuri, merampok dan sejenisnya. Harta tidak hanya digunakan untuk kegiatan konsumsi atau investasi, tetapi juga perlu didistribusikan melalui zakat, infaq, dan sedekah.

Kedua, kebutuhan hajiyyah adalah kebutuhan sekunder, dimana dalam tingkatan ini jika kebutuhan tersebut tidak dapat diwujudkan maka tidak sampai mengancam keselamatannya, namun akan mengalami hambatan dan kesulitan. Ketiga, kebutuhan tahsiniyyah adalah tingkatan kebutuhan yang jika tidak dipenuhi, maka tidak akan mengancam eksistensi salah satu dari lima hal pokok maqashid syariah dalam kebutuhan daruriyyah dan tidak menimbulkan kesulitan. Tingkatan ini adalah tingkatan tersier (Anwar (2003) dalam Anshori 2003).

\section{Relevansi Maqashid Syariah yang Diper- luas dalam Menilai Kelayakan Bisnis}

Aturan syariat yang ada dalam AlQur'an dan As-Sunnah, kemudian dijabarkan lagi melalui ijma' dan qiyas (bagian dari ijtihad) dalam rangka untuk memenuhi kebutuhan praktik saat ini. Ijma' dan qiyas sering digunakan oleh para ulama dalam menentukan hukum praktik muamalah agar praktik muamalah tetap memenuhi maqashid syariah.

Melihat perkembangan jaman modern yang lebih kompleks, muncullah wacana untuk mengembangkan konsep maqashid syariah sesuai dengan kondisi saat ini. Munculnya fenomena kerusakan lingkungan mendorong adanya wacana menambah maqashid syariah dengan pemeliharaan lingkungan (Jamaa 2011). Hal ini mengacu pada dalil dalam Al-Qur'an, yaitu:
"Telah tampak kerusakan di da- rat dan di laut disebabkan karena perbuatan tangan manusia; Allah menghendaki agar mereka mera- sakan sebagian dari (akibat) per- buatan mereka, agar mereka kem- bali (ke jalan yang benar)" (QS Ar- Rum 30:41).

Keberadaan konsep maqashid syariah, ternyata dapat memberikan solusi dalam menjawab berbagai masalah yang tidak diatur oleh wahyu secara tekstual dan kontekstual, termasuk pula dalam melakukan penilaian kelayakan suatu bisnis. Sehingga, diharapkan kriteria penilaian bisnis tidak menyimpang dari tujuan syariah itu sendiri. Artikel ini menggunakan perspektif maqashid syariah dengan menambahkan tujuan memelihara lingkungan dan persaudaraan (ukhuwah) (Jamaa 2011), tetapi tidak membahas tujuan memelihara keturunan.

\section{Metodologi Menurut Perspektif "Mamah Dedeh"}

Munculnya paradigma baru membuka peluang penelitian untuk dapat menggunakan turunan metodologi yang beragam. Ragam ini tentunya tidak lepas dari kesesuaian dengan topik dan sudut pandang peneliti. Artikel ini menggunakan metodologi dari teori Mamah Dedeh. Metodologi diturunkan dari karakteristik dan cara berdakwah $\mathrm{Ma}$ mah Dedeh sebagai cara untuk membangun kelayakan bisnis yang sesuai dengan fitrah Islam.

Mamah Dedeh yang memang mengabdikan diri untuk berdakwah memiliki gaya tersendiri hingga beliau mampu merangkul jamaah dari berbagai kalangan, mulai dari lingkup kecil ibu-ibu di kampung, hingga di kementerian. Hal ini menunjukkan kesuksesan Mamah Dedeh sebagai seorang ustadzah (perempuan) yang dapat terjun langsung secara aktif dalam dakwah. Hingga 
seringkali dalam suatu acara Tabligh Akbar, Mamah Dedeh ikut dilibatkan dalam ceramah dengan beberapa penceramah laki-laki (ustadz).

Keberhasilan saat ini Mamah Dedeh yang mampu memberikan penyadaran akan pentingnya syariat bagi masyarakat luas lebih ditekankan dalam artikel ini. Sehingga, teori Mamah Dedeh dapat dinyatakan sebagai upaya penyadaran beragama secara langsung dengan tunduk pada syariat yang ditentukan oleh Allah SWT dan disampaikan melalui rasul-Nya, Nabi Muhammad SAW, melalui cara yang sederhana, tetapi mengena.

Teori tentunya memerlukan asumsi yang mendasari. Asumsi yang dapat ditarik berdasarkan biografi maupun cara berdakwah Mamah Dedeh, antara lain (1) Berada di jaman kontemporer dimana kehidupan modern semakin meluas, tetapi di sisi lain jumlah masyarakat Muslim semakin banyak; (2) Adanya pengikisan moralitas dalam kehidupan masyarakat sebagai dampak aktivitas yang bersifat kontemporer; (3) Perlunya masyarakat dibekali pengetahuan agama Islam untuk menghadapi dan memperkokoh Iman; (4) Penyadaran beragama dilakukan secara langsung dengan cara menjawab permasalahan (berbasis masalah); (5) Berusaha untuk menjawab semua pertanyaan, bahkan melalui telepon dan sms setelah mengisi kajian; (6) Memberikan jawaban secara mantap, lugas, tanpa ragu dan dengan kalimat yang mudah untuk mendorong jamaah agar memperoleh kemantapan dalam berIslam berbasis dalil dalam Al-Qur'an dan Hadits; (7) Aktif baik di dunia nyata maupun maya (televisi) demi terjangkaunya berbagai lapisan masyarakat; serta (8) Pengabdian dalam berdakwah karena dakwah merupakan kewajiban untuk menyebarkan Islam rahmatan lil 'alamiin kepada seluruh umat manusia.

Asumsi-asumsi tersebut, secara keseluruhan, berujung pada cara dakwah yang tercapai "tujuan" dakwahnya melalui caracara khas Mamah Dedeh. Dalam memberikan tausiyah, Mamah Dedeh menyesuaikan dengan jaman sekarang yang sulit menerima keseriusan, tetapi melalui keakraban dalam mencari penyelesaian masalah. Hidup tetap patuh pada syariat, tetapi jangan dibuat sulit, sehingga pendekatan Mamah Dedeh sangatlah efektif.

Jika bisnis saat ini masih bersifat materialistik yang mengabaikan aspek-aspek
Ilahi yang lain, maka teori Mamah Dedeh dapat digunakan untuk merekonstruksi studi kelayakan bisnis saat ini yang masih bersifat "kontemporer" mengikuti modernitas, dengan cara mudah dan mengena, serta mengacu pada dalil di Al-Qur'an dan Hadits agar kembali memahami nilai-nilai Islam untuk dapat diterapkan dalam bermuamalah. Langkah-langkah yang dapat dilakukan mengacu pada asumsi yang dijelaskan sebelumnya, sebagai berikut. Pertama, memahami segala seluk-beluk studi kelayakan bisnis konvensional yang banyak diajarkan saat ini. Hal ini dapat dilakukan dengan memperoleh data dokumen tertulis (artikel atau dokumen terkait lainnya, baik yang dipublikasikan dan tidak dipublikasikan) atau dari sumber pelaku/investor (melalui kata-kata dan tindakan). Data sekunder dan primer sama-sama digunakan dalam tahap ini (Moleong 2004:157).

Kedua, mengkaji studi kelayakan bisnis konvensional yang mengikis moral pelaku. Tahap ini sudah memasuki tahap analisis data dengan melihat hasil observasi, wawancara, dan lainnya. Ketiga, perkembangan jaman yang begitu cepat membutuhkan adanya ijtihad yang dapat menjawab masalah yang ada (berbasis masalah). Sehingga, masalah yang terkandung dalam kelayakan bisnis konvensional dijadikan acuan untuk menemukan solusi perbaikan. Dalam artikel ini, "basis masalah" akan diwujudkan dengan turun ke lapangan (wawancara) untuk melihat praktik kelayakan bisnis yang dilakukan oleh salah satu Usaha Mikro, Kecil, dan Menengah (UMKM) di Malang, yaitu Abah Odil sebagai informan.

Keempat, masalah yang ada dapat berskala besar maupun kecil, atau sepele. Namun, penyelesaian masalah itu tidak dapat dilakukan untuk yang besar-besar saja, tetapi yang kecil juga perlu diselesaikan secara tuntas karena jika dibiarkan, sesuatu yang kecil dapat menjadi besar. Selain itu, pembahasan terkait masalah dalam kelayakan bisnis dinyatakan secara lugas. Kelima, perbaikan untuk membangun kelayakan bisnis secara Islam harus didasarkan pada dalil-dalil dalam Al-Qur'an dan Hadits untuk memberi kemantapan terhadap ketentuan syariat. Jika memang telah sesuai, dapat dipertahankan. Namun, jika terdapat hal-hal yang belum sesuai, maka perlu ada perbaikan.

Keenam, solusi yang ditawarkan mampu diaplikasikan oleh para pengguna secara 
menyeluruh, tidak hanya pada masyarakat tertentu. Ketujuh, dakwah terus dilakukan untuk mendekatkan diri kepada Allah SWT, khususnya yang bersifat ibadah dan dilengkapi dengan mu'amalah. Kelayakan bisnis seharusnya dilakukan sebagai upaya mendekatkan diri kepada Allah SWT. Sehingga, dakwah dapat dilakukan salah satunya melalui tulisan yang dapat memberikan penyadaran berupa studi kelayakan bisnis berbasis Islam yang dapat memberikan maslahat.

\section{HASIL DAN PEMBAHASAN}

\section{Memahami dan Mengkaji Nilai-Nilai Kon- vensional dalam Studi Kelayakan Bisnis}

Studi kelayakan menitikberatkan pada apakah bisnis layak dan dapat dijalankan dengan melihat aspek pasar, keuangan, dan teknologi. Jika hasil studi kelayakan positif, maka bisnis dapat dijalankan (Matson 2000). Maksud dari bisnis dapat dijalankan adalah dapat memberikan pengembalian positif di masa depan dengan kondisi pasar yang menerima produk yang dihasilkan.

Tingkat pengembalian tidak akan lepas dari risiko, sehingga studi kelayakan bisnis selalu menekankan pada penilaian risiko yang memang ada di setiap lini. Selain itu, mempertimpangkan pula atas permintaan produk di masa depan, apakah produk masih berprospek atau tidak, serta menimbangnimbang sumber daya yang bisa mendukung tingkat laku suatu barang. Harapan mengecilnya risiko seminimal mungkin hingga keberlangsungan bisnis dalam jangka panjang, menunjukkan kekhawatiran dalam jiwa yang bersifat duniawi. Hal ini menunjukkan bahwa hanya proses ikhtiar saja yang dilakukan dalam studi konvensional, yang belum tentu pula prosesnya sesuai dengan syariat. Padahal di dalam Islam, umat muslim diminta tidak hanya ikhtiar (berusaha), tetapi juga doa, tawakal, dan ihsan.

Menahan risiko untuk meningkatkan return dan dapat bertahan hidup dalam jangka panjang, berusaha memastikan sesuatu yang tidak pasti di masa depan. Padahal, segala sesuatunya akan kembali kepada Allah SWT dan tidak ada yang tahu pasti seberapa jangka waktu yang dimiliki, sesuai dengan ayat berikut.

"Dan Kepunyaan Allah-lah kerajaan langit dan bumi serta apa yang ada antara keduanya. Dan kepada Allah-lah kembali (segala sesuatu)" (QS. Al-Maidah 5:18).
Studi kelayakan bisnis konvensional dapat menggiring kita untuk selalu berpikir segmentasi pasar untuk menilai waktu pengembalian investasi secepat mungkin. Akal seringkali hanya digunakan untuk berpikir logika atas sesuatu yang tampak dengan menghilangkan intuisi dan koridor agama.

Studi kelayakan bisnis konvensional dengan tujuan utama keuntungan, menggunakan analisis keuangan, analisis ekonomi, hingga penilaian risiko untuk meningkatkan return, yang semua berujung pada satu titik, yaitu bertambahnya harta bagi investor. Perhitungan pengembalian menunjukkan bahwa kebanyakan pengusaha industri dan modern yang merefleksikan, baik produksi dan pendekatan modal (Toms 2010). Hal ini identik dengan proses penumpukan harta. Selain itu, mencari untung maksimal dengan menganalisis ekonomi (permintaan dan penawaran) untuk melihat peluang produk laku di lapangan. Begitu pula dengan modal (harta yang dimiliki) yang hanya digunakan untuk investasi menguntungkan. Sesuai dengan dalil berikut.

"Bermegah-megahan telah melalaikan kamu. Sampai kamu masuk ke dalam kubur. Janganlah begitu, kelak kamu akan mengetahui (akibat perbuatanmu itu). Dan janganlah begitu, kelak kamu akan mengetahui. Janganlah begitu, jika kamu mengetahui dengan pengetahuan yang yakin. Niscaya kamu benar-benar akan melihat neraka Jahiim. Dan sesungguhnya kamu benar-benar akan melihatnya dengan 'ainul yaqin. Kemudian kamu pasti akan ditanyai pada hari itu tentang kenikmatan (yang kamu megahmegahkan di dunia itu)" (QS. AtTakatsur 102:1-8).

Rahmatan lil 'alamin bermaksud untuk memberikan rahmat semesta alam, tidak hanya manusia, tetapi juga lingkungan. Wacana memperhatikan lingkungan memang sudah banyak muncul dalam akuntansi atau bisnis konvensional. Namun, penilaian kelayakan bisnis konvensional belum secara nyata menyatakan perlunya lingkungan sebagai indikator menilai bisnis layak dijalankan atau tidak.

Istilah persaudaraan (ukhuwah) tidak pula dikenal dalam sistem konvensional, ter- 
masuk studi kelayakan bisnis konvensional. Segala sesuatu yang dilakukan masih bersifat self interest yang egoistik. Sifat ini tampak adanya kepentingan yang besar terhadap return yang ingin diperoleh.

Lebih lanjut, egoistik yang mementingkan diri sendiri merupakan sumber penyakit yang akan mempengaruhi kebahagiaan hidup. Egoistik akan menciptakan realitas yang juga egoistik, pada akhirnya tercipta realitas yang destruktif baik pada lingkungan fisik, psikis, dan spiritual manusia (Triyuwono 2012). Egoistik juga pada akhirnya akan menghasilkan manusia yang lebih mementingkan diri sendiri dengan mengesampingkan pentingnya persaudaraan dengan sesama manusia, khususnya sesama umat muslim (ukhuwah).

\section{Usulan Kelayakan Bisnis yang Memiki Tu- juan Syariah (Maqashid Syariah yang Di- perluas)}

Abah Odil merupakan informan dalam artikel ini. Abah Odil adalah sebuah merek bubur ayam khas Tasikmalaya. Usaha bubur ini termasuk dalam usaha mikro, kecil, dan menengah yang dibangun sejak tahun 2004. Pemiliknya bernama lengkap Ate Rushendi, yang kemudian dipanggil dengan nama panggilan "Abah". Abah memiliki cerita sejak bagaimana dia mendirikan usaha dan menjalankannya hingga saat ini. Berikut akan dibahas satu persatu hasil wawancara dengan Abah Odil, yang kemudian dapat dijadikan acuan dalam mengusulkan perbaikan atas studi kelayakan bisnis saat ini.

\section{Memelihara Agama}

Pada saat awal akan menentukan bisnis yang akan dijalankan (sebelum memulai), Abah Odil menyatakan bahwa perlunya menjaga takwa pelaku yang bersangkutan, seperti disampaikan sebagai berikut.

"Dengan menjaga takwa, akan dibukakan jalan dan pintu rezeki dari arah mana saja."

Hal ini sesuai dengan ayat Al-Qur'an:

"Dan memberinya rezeki dari arah yang tiada disangka-sangkanya. Dan barangsiapa yang bertawakkal kepada Allah niscaya Allah akan mencukupkan (keperluan) nya. Sesungguhnya Allah melaksanakan urusan yang (dikehendaki)Nya. Sesungguhnya Allah telah mengadakan ketentuan bagi tiap-tiap sesuatu." (QS. AthThalaq 65:3).

Mengikutsertakan takwa merupakan hal yang penting, yaitu taat pada syariat dengan mematuhi perintah dan menjauhi larangan-Nya. Selain itu, dalam memulai bisnis pertama kali adalah niat bisnis itu sendiri, apakah bertujuan untuk Allah SWT dan di jalan Allah SWT, atau tidak. Umat Muslim seharusnya mematok segala sesuatu kepada Allah SWT. Hal ini sesuai dengan hadits sebagai berikut.

"Sesungguhnya setiap amal perbuatan tergantung pada niatnya. Dan sesungguhnya setiap orang (akan dibalas) sesuai dengan niatnya. Barangsiapa yang hijrahnya karena Allah dan Rasul-Nya, maka hijrahnya kepada Allah dan Rasul-Nya. Dan barangsiapa yang hijrahnya karena urusan dunia yang ingin digapainya atau karena seorang wanita yang ingin dinikahinya, maka hijrahnya sesuai dengan apa yang diniatkannya tersebut." (HR. Bukhari dan Muslim).

Dengan demikian, jika segala sesuatunya dikembalikan untuk agama. Allah SWT mensyariatkan agama yang wajib dipelihara oleh setiap orang, baik yang berkaitan dengan ibadah, aqidah, maupun muamalah, sesuai dengan dalil berikut.

"Hai manusia, sembahlah Tuhanmu yang Telah Menciptakanmu dan orang-orang yang sebelummu, agar kamu bertakwa." (QS. Al-Baqarah 2:21).

\section{Memelihara Jiwa}

Saat Abah Odil akan memulai bisnisnya, Abah Odil memberanikan diri keluar dari pekerjaan sebelumnya dengan kondisi kondisi keuangan yang minim. Namun, Abah Odil menilai bahwa bisnis yang dilakukan (dengan cara yang baik tentunya) menjadi layak dijalankan jika mampu menjadi media untuk berserah diri kepada Allah SWT. Hal ini dilakukan dengan tawakal kepada Allah SWT dengan menyatakan:

"Segala sesuatunya adalah punya

Allah, gak ada yang mutlak."

Sebagai manusia kita harus menyadari bahwa segala sesuatunya milik Allah SWT 
dan kita hanya sebagai pengelola bumi sesuai dengan syariatnya. Triyuwono (2012) menyebutnya dengan khalifatullah fil ardh, yaitu manusia mengelola bumi untuk menyebar kesejahteraan. Hal ini sesuai dengan:

"Kepunyaan Allah-lah segala yang ada di langit dan di bumi; dan kepada Allahlah dikembalikan segala urusan" (QS. Ali Imran 3:109).

Oleh karena itu, bisnis dapat pula dinilai layak/tidak dengan melihat apakah mampu membuat pelaku tunduk sebagai hamba Allah. Sikap tunduk kepada Allah SWT ditunjukkan dengan mempertimbangkan kelayakan bisnis berdasarkan kemampuan bisnis tersebut untuk menjadi media mendekatkan diri kepada Allah SWT, dan bukannya malah menjauhkan. Tujuannya tetap sama yaitu memelihara jiwa agar ikhlas dalam menjalankan segala sesuatu karena Allah SWT dan di jalan Allah SWT. Hal ini merupakan modal non-materi yang menjadi pelengkap bagi modal materi berupa harta.

\section{Memelihara Akal}

Salah satu cara untuk melindungi akal adalah menghindari hal-hal yang merusak, seperti minum minuman yang memabukkan yang dapat menghilangkan akal menusia. Produk halal menjadi poin penting sebagai wujud pemenuhan produk yang baik bagi tubuh dan menjaga akal manusia. Produk halal sekaligus thayyib (baik) yang sesuai dengan ketentuan syariat menjadi hal yang mutlak untuk dipatuhi kaum muslimin, seperti dinyatakan ayat sebagai berikut.

"Hai sekalian manusia, makanlah yang halal lagi baik dari apa yang terdapat di bumi, dan janganlah kamu mengikuti langkah-langkah syaitan, karena sesungguhnya syaitan itu adalah musuh yang nyata bagimu" (QS. Al-Baqarah $2: 168)$.

Bisnis dinilai kelayakannya berdasarkan apakah bisnis ini dapat memberikan output halal dengan proses yang halal dan thayyib pula. Hal ini akan memberikan dampak bagi pelaku/investor sendiri maupun kemslahatan pula bagi masyarakat sekitar.

\section{Memelihara Harta}

Abah Odil memiliki pandangan berbeda terkait harta yang diputar untuk berbisnis. Bahkan, Abah Odil tidak mempersalahkan kondisi sebelumnya yang ia pernah menjadi manajer perusahaan, untuk kemudian turun langsung mendorong gerobak untuk berjualan, seperti disampaikan saat Abah pertama kali memulai bisnisnya sebagai berikut.

"Untuk memberikan kebaikan bagi oang lain, seperti membuka lapangan kerja, wujud ibadah, dan media untuk berinfaq. Keluar uang, insyaAllah akan dibalas oleh Allah nantinya. Sehingga, setiap hari selalu ada yang disisihkan, seperti zakat."

Menurut maqashid syariah, harta memiliki tujuan, yaitu tadawul (berputar), wudluh (jelas), dan 'adl (ditempatkan sesuai tempatnya). Harta harus diputar (tadawul), yaitu tidak boleh berdiam di orang-orang kaya saja, tidak boleh dihitung-hitung, dan tidak ditumpuk. Cara memutar dilakukan dengan tiga hal, yaitu (1) Konsumsi, misalnya untuk makan tidak berlebihan; (2) Produksi, dorongan fitrah manusia bahwa harta tidak hanya untuk dirinya tetapi juga keturunan, sehingga harus diinvestasikan; serta (3) Distribusi kekayaan, seperti melalui infaq, sedekah, zakat, dan sebagainya untuk meningkatkan persaudaraan, yang didukung dengan dalil-dalil sebagai berikut.

"Dan dirikanlah shalat, tunaikanlah zakat dan ruku'lah beserta orang-orang yang ruku' " (QS. AlBaqarah 2:43).

"Siapakah yang mau memberi pinjaman kepada Allah, pinjaman yang baik (menafkahkah hartanya di jalan Allah), maka Allah akan melipat gandakan pembayaran kepadanya dengan lipat ganda yang banyak. Dan Allah menyempitkan dan melapangkan (rezeki) dan kepada-Nya lah kamu dikembalikan"

(QS. Al-Baqarah 2:245).

"Orang-orang yang menafkahkan hartanya di malam dan siang hari secara tersembunyi dan terangterangan, maka mereka mendapat pahala di sisi Tuhannya. Tidak ada kekhawatiran terhadap mereka dan tidak (pula) mereka bersedih hati"

(QS. Al-Baqarah 2:274). 
Sebagaimana penjelasan beberapa dalil tersebut, bisnis dapat dinyatakan layak/tidak jika mampu membuat harta berputar dengan tiga cara tersebut, yaitu (1) Investasi untuk memberikan kebaikan atas harta, (2) Konsumsi yang baik yang sesuai dengan porsi kebutuhan, dan (3) Memiliki tujuan akhir untuk distribusi kekayaan bagi pihakpihak yang membutuhkan.

\section{Memelihara Lingkungan}

Abah Odil sebagai pebisnis kuliner bubur tidak terlalu berhadapan dengan masalah lingkungan. Limbah yang dihasilkan bukan merupakan limbah beracun yang bersinggungan dengan lingkungan. Namun, Islam juga mengatur pentingnya memelihara lingkungan, apalagi praktik bisnis industri saat ini yang menghasilkan limbah yang seringkali berbahaya bagi lingkungan maupun manusia yang lain. Hal ini sesuai dengan dalil berikut.

"Telah tampak kerusakan di darat dan di laut disebabkan karena perbuatan tangan manusia; Allah menghendaki agar mereka merasakan sebagian dari (akibat) perbuatan mereka, agar mereka kembali (ke jalan yang benar)" (QS. ArRum 30:41).

\section{Memelihara Ukhuwah}

Abah Odil bertekad untuk menjalankan usaha yang bisa memberikan kebaikan bagi orang lain, membuka lapangan kerja, dan ibadah. Abah meninggalkan pekerjaan lamanya karena merasa terlalu duniawi dan beralih untuk berwirausaha untuk memberikan banyak kebaikan bagi sesama umat Muslim.

Hal ini terwujud dalam proses bisnis yang dijalankan Abah Odil. Berikut pemaparan Abah:

"Karyawan yang direkrut harus memenuhi beberapa syarat antara lain sholat lima waktu, tidak boleh merokok (jika awalnya merokok, maka harus mau berhenti), ikut mengaji satu kali seminggu. Tujuannya agar barokah. Karyawan juga digaji dengan sistem payroll untuk mengangkat karyawan dan membiasakan mereka untuk menabung. Selain itu, mereka juga dibiasakan untuk berinfaq setiap hari Jum'at."
Pemaparan Abah tersebut menunjukkan bahwa memberdayakan orang lain adalah perlu, dalam hal ini karyawan. Abah mengangkat derajat mereka dengan izin Allah SWT. Abah juga telah menjalin suatu silaturahmi yang mengikat dengan karyawannya. Semua ini merupakan wujud membantu/memudahkan dan memberi manfaat bagi kehidupan umat sesama Muslim. Menjaga persaudaraan telah dinyatakan dalam dalil berikut.

\begin{abstract}
"Dan bertaqwalah kepada Allah yang dengan mempergunakan nama-namaNya, kamu saling meminta, dan (peliharalah) hubungan silaturahmi" (QS. An Nisa 4:1).

"Sesungguhnya orang-orang muk-
min adalah bersaudara, karena itu
damaikanlah antara kedua sauda-
ramu dan bertakwalah kepada Al-
lah supaya kamu mendapat rah-
mat" (QS. Al Hujuraat 49:10).
\end{abstract}

"Seorang mukmin terhadap mukmin (lainnya) bagaikan satu bangunan, satu sama lain saling menguatkan" (HR. Bukhari dan Muslim).

Oleh karena itu, bisnis juga harus dinilai kelayakan dari sisi apakah mampu mewujudkan ukhuwah (persaudaraan) dengan sesama umat Muslim. Syarat paling minimal adalah membentuk persaudaraan dengan karyawan, supplier, dan pelanggan. Lebih luas lagi, bisnis seharusnya dapat memberi manfaat bagi masyarakat secara umum di luar bisnis yang bersangkutan.

\section{SIMPULAN}

Islam adalah rahmatan lil 'alamiin (rahmat bagi seluruh alam). Diutusnya Nabi Muhammad SAW adalah untuk membawa syariat yang merupakan rahmat bagi seluruh alam. Para ulama ushul figh mengartikan rahmat dengan menggunakan istilah kemaslahatan yang selanjutnya dikenal dengan istilah Maqashid al-Syariah.

'Maqashid Syariah yang diperluas dijadikan sebagai suatu perspektif untuk mengusulkan studi kelayakan bisnis yang sesuai dengan koridor syariah. Wacana 'maqashid syariah yang diperluas menyesuaikan dengan konteks kekinian, yaitu dengan menambahkan tujuan memelihara lingkungan dan persaudaraan (ukhuwah), tetapi tidak memasukan tujuan memelihara keturunan. 
Teori Mamah Dedeh digunakan untuk membangun studi kelayakan bisnis, yaitu didasarkan pada biografi dan cara dakwah yang digunakan oleh Mamah Dedeh. Teori dapat dinyatakan sebagai upaya penyadaran beragama secara langsung dengan tunduk pada syariat yang ditentukan oleh Allah SWT dan disampaikan melalui rasul-Nya, Nabi Muhammad SAW, melalui cara yang sederhana, tetapi mengena. Teori tentunya memerlukan asumsi yang mendasari dan kemudian diturunkan menjadi metodologi.

Usulan atas studi kelayakan bisnis berbasis Islam yang dapat memberikan maslahat, antara lain: (1) Perlunya menjaga takwa, niat bisnis untuk Allah SWT dan di jalan Allah SWT; (2) Mampu membuat pelaku tunduk sebagai hamba Allah yang akan mampu memelihara jiwa dan media mendekatkan diri kepada Allah SWT; (3) Melindungi akal dengan menghindari hal-hal yang merusak, yaitu melalui produk halal sekaligus thayyib (baik); (4) Harta harus berputar, tidak boleh berdiam di orang-orang kaya saja (seperti pemilik), tidak boleh dihitung-hitung, dan tidak ditumpuk. Harta diputar dengan melakukan konsumsi, produksi, dan distribusi kekayaan (seperti melalui infaq, sedekah, dan zakat; (5) Pentingnya memelihara lingkungan; serta (6) Usaha yang bisa menjalin persaudaraan dengan pihak-pihak lain, baik yang terlibat langsung dengan perusahaan ataupun tidak langsung.

Artikel ini memiliki keterbatasan bahwa usulan masih bersifat normatif dan belum mencapai tataran teknis secara keseluruhan. Selain itu, tataran filosofis dan metodologi merupakan usulan dari pribadi penulis yang masih terdapat banyak kekurangan.

\section{DAFTAR RUJUKAN}

Al-Qur'an dan Hadits.

Anshori, Isa. 2003. Maqashid Al-Syari'ah Sebagai Landasan Etika Global. Jurnal Hukum Islam Kopertais Wilayah IV Surabaya. Jakarta: PT. Serambi Ilmu Semesta.

Björnsdóttir, Anna Regína. 2010. Financial Feasibility Assessments. Thesis. Faculty of Industrial Engineering, Mechanical Engineering and Computer Science University of Iceland.
Directorate General Regional Policy - European Comission. 2008. Guide to CostBenefit Analysis of Investment Projects.

Faruqi, Ismail Raji al. 1998. Al-Tawhid: Its Implications for Thought and Life. International Institute of Islamic Thought, Herndon, Virginia, USA.

Graaskamp, James A. 1972. A Rational Approach to Feasibility Analysis. The Appraisal Journal.

Hofstrand, D. dan M. Holz-Clause. 2009. Feasibility Study Outline. Iowa State University. (Online), diakses 20 Desember 2013.

Jamaa, La. 2011. "Dimensi Ilahi dan Dimensi Insani dalam Maqashid al-Syariah." Jurnal Ilmu Syariah dan Hukum. Vol. 45 No. II.

Karim, Adimarwan A. 2011. Bank Islam: Analisis Fiqih dan Keuangan. Edisi Keempat. PT Jaka Grafindo Persada. Jakarta

Mackey, John. 2007. Conscious Capitalism Creating a New Paradigm for Business.

Matson, J. 2000. Cooperative Feasibility Study Guide. USA: United States Department of Agriculture. Rural Business - Cooperative Service. (Online), diakses 20 Desember 2013.

Moleong, Lexy J. 2004. Metode Penelitian Kualitatif. Bandung: PT. Remaja Rosdakarya.

Mubarak, Jaih. 2002. Metodologi Ijtihad Hukum Islam. UII Press. Yogyakarta

Nasr, V. 2009. The Rise of Islamic Capitalism: Why the New Muslim Middle Class is the Key to Defeating Extremism. Free Press. New York.

Thompson, Alan. 2003. Understanding the Proof of Business Concept. Murdoch Business School.

Toms, J. S. 2010. "Calculating Profit: A Historical Perspective on the Development of Capitalism." Accounting, Organizations and Society. Vol. 35.

Triyuwono. Iwan. 2012. Akuntansi Syariah Perspektif, Metodologi, dan Teori. PT Raja Grafindo Persada. Jakarta

Weber, Max. 1927. General Economic History. (books.google.co.id), diakses 10 Desember 2013.

Zein, Satria Effendi M. 2005. Ushul Figh. Cetakan Pertama. Penerbit Kencana. Jakarta 